\title{
PENSAR A AlCA
}

A NTONIO DELFIM NETTO Professor Catedrático da Faculdade de Econômia da Universidade de São Paulo 

O Brasil precisa reaprender rapidamente a pensar o seu futuro para poder apontar com clareza quais os interesses nacionais de seus cidadãos, que devem ser defendidos nas discussões para o ingresso na Associação de Livre Comércio das Américas. A realização dessa tarefa vai exigir a mobilização do pensamento acadêmico, dos empresários, dos trabalhadores e das representações do Legislativo e do Judiciário e do Poder Executivo. Esse envolvimento é necessário porque se trata de definir em que condições vamos entrar em uma parceria com o poder hegemônico que hoje comanda a economia mundial. Ou, não vamos?

É preciso entender, inicialmente, que a Alca é um desejo do sistema produtivo dos Estados Unidos, que vê nela a possibilidade de consolidar e ampliar seus negócios em toda a América. A história norte-americana mostra um país com notável capacidade de pensar o futuro. Os Estados Unidos são o que são porque, desde a sua fundação, cuidaram duramente dos seus interesses. E os interesses norte-americanos são a soma dos interesses de seus cidadãos, de sua agricultura, de sua indústria e de seu comércio, no país e no exterior. Até hoje a lei norte-americana pretere todas as demais e seus interesses preterem todos os outros.

A pressa norte-americana para constituir a Alca é apenas mais um passo no prístino desejo, nascido com a Doutrina Monroe em I823, de construir um campo de caça privilegiado para os seus interesses. A proposição que "qualquer zona de livre comércio aumenta o bem-estar de seus participantes" não faz parte da ciência econômica: é pura manifestação do pensamento ideológico hegemônico construído por uma certa "ciência norte-americana". Esta é contrabandeada para o mundo subdesenvolvido na cabeça de alguns bolsistas mesmerizados pela busca de sucesso e reconhecimento de seus mestres.

Devemos olhar para os Estados Unidos e ver o que eles fizeram, não fazer o que eles recomendam. Uma primeira boa leitura seria o famoso Relatório Sobre as Manufaturas que um dos "pais fundadores", o Secretário do Tesouro Alexander Hamilton, submeteu ao Congresso em I791. Nele estão os primorosos argumentos que embasaram toda uma política de proteção à nascente indústria norte-americana. Seus princípios tiveram enorme influência na deter- 
minação das políticas econômicas que produziram o desenvolvimento do país. A abertura do mercado interno norte-americano, guardadas inúmeras limitações e restrições setorizadas, é coisa muito recente. Basta lembrar que até as proximidades da Segunda Guerra Mundial, na década de I930, as receitas alfandegárias constituíam o item mais importante da arrecadação tributária norteamericana. Os competidores dos Estados Unidos destruíram-se na guerra e eles impuseram uma "ordem mundial" com o Fundo Monetário (FMI), o Banco Internacional para Reconstrução e Desenvolvimento (Bird) e o Acordo Geral de Tarifas e Comércio (Gatt, hoje OMC) que continuam sob seu controle. Foram também generosos com vencidos e com seus parceiros na vitória ao lançarem o Plano Marshall, por exemplo. E permitiram que os três maiores adversários (Alemanha, Itália e Japão) recebessem as bênçãos de uma taxa de câmbio subvalorizada que estimulou fortemente a reconstrução de suas economias de I950 até praticamente I970. Ao contrário, portanto, do que pensam os malresolvidos com a vida, os Estados Unidos não devem ser odiados. Devem ser admirados e imitados...

Os que sabem que a Geografia e a História condicionam a transformação da teoria econômica em política econômica, também sabem que nenhum país tem hoje o grau de liberdade que os Estados Unidos gozaram para realizar o seu extraordinário desenvolvimento. O Brasil está numa posição parecida com a dos Estados Unidos em I9०0, mas inserido na estrutura política e econômica condicionada pela nova "ordem mundial" vigente nesse início de século 2I.

O Brasil está sendo empurrado para a Alca. O tempo vai se esgotando, e nossa capacidade para sustentar com argumentos sólidos nossa posição não está sendo construída. Não é possível deixar isso nas mãos dos burocratas, mesmo os mais competentes. Não é possível deixar de forçar uma discussão ampla com a Academia, com o setor privado e com o Congresso. Felizmente já surgem algumas iniciativas nessa direção: o presidente da Câmara Federal, deputado Aécio Neves, recém-aprovou a formação de uma comissão suprapartidária, que se reunirá no início deste segundo semestre para uma série de audiências públicas em que se pretende aprofundar a discussão sobre a Alca. É a oportunidade para que os diferentes setores da sociedade se manifestem e apresentem seus argumentos quanto à conveniência (ou não) e sobre as condições de nossa participação, resguardando os interesses dos cidadãos e dos setores produtivos nacionais.

Nossos diplomatas são extremamente competentes, mas não lhes cabe formular a política de integração comercial. Cabe à sociedade e ao Congresso, com o suporte da inteligência acadêmica de que dispomos e da experiência do setor privado, aprofundar essa análise e tentar entender o que será a economia brasileira dentro da Alca. A rigor, não se pode ser nem a favor nem contra, por- 
que dispomos de poucos estudos a respeito. De fato, não temos as informações necessárias. Talvez estejamos sendo injustos, mas não acreditamos que o governo disponha de um estudo sério, profissional, sobre as conseqüências para a economia brasileira de sua integração na Alca. E, o que é pior, não dispomos de um contraditório acadêmico capaz de lançar luz sobre o problema sob as mais diversas perspectivas teóricas e empíricas. A idéia de que, em quaisquer circunstâncias, uma associação de livre comércio só traz benefícios não é uma proposição científica: é uma manifestação de fé religiosa.

Existem, não obstante, algumas questões de natureza prática que devem ser resolvidas preliminarmente, como reclamou, num feliz discurso, o presidente Fernando Henrique Cardoso na reunião de Chefes de Estado realizada em abril em Quebec. A primeira delas é a necessidade de regular a legislação antidumping norte-americana, sem o que nossa participação na Alca pode ser indesejável. Até Alan Greenspan reconhece que "muitas vezes são impostas (medidas) em nome da justiça comercial, mas freqüentemente o são para impedir a competição". Por isso justifica-se a afirmação do presidente ao defender a administração compartilhada do problema: "não vamos entrar nesse jogo como um país que não tem voz ou com mentalidade colonizada. Como se fosse um favor para nós entrar na Alca. Não é. É negócio, toma lá, dá cá...”.

O presidente referiu-se, também, às restrições não-tarifárias (trabalhistas, sanitárias e ambientais) que freqüentemente introduzem um protecionismo velado sob a cobertura de baixas tarifas. Nesse ponto, seu discurso coincide com o do presidente Bush, com uma perspectiva diferente, condenando o "protecionismo autodestruidor" que se esconde por detrás daquelas restrições.

Não há garantia de que se possam extrair conseqüências práticas desses discursos, mas, como se vê, há um amplo espaço para se definir importantes questões preliminares ao nosso ingresso na Alca. 